\title{
ANALISIS PENGARUH PENAMBAHAN BERAT BADAN, KADAR HEMOGLOBIN, DAN RIWAYAT PENYAKIT IBU SELAMA HAMIL DENGAN BERAT BAYI LAHIR PADA KONDISI BERAT BAYI LAHIR RENDAH (BBLR)
}

\author{
(Study Observasi di RSIA Fauziyah Tulungagung) \\ Ratna Kholidati \\ STIKes Hutama Abdi Husada Tulungagung \\ nadasalma12@gmail.com
}

\begin{abstract}
Low Birth Weight $(L B W)$ is a health problem that is often experienced in most societies characterized by birth weight less than 2500 grams. The occurrence of $L B W$ is basically related to the lack of nutritional fulfillment during the mother's pregnancy and this is related to many factors and more mainstay on family economy problem so that the fulfillment of food consumption need is less. This study aims to analyze the effect of weight gain, hemoglobin level, and history of maternal disease during pregnancy with birth weight in low birth weight (LBW). This type of research is analytical through surveys using observation. Observation is done by using a mother's status card or medical record file. Samples in this research are all babies born in Maternal and Fauziyah Hospital Tulungagung in March 2016 as many as 30 babies. Measurement of variables in this study using Likert scale. The sampling technique uses saturated sampling. Data were analyzed by using simple linear regression analysis. The results showed for the hypothesis of selfinfluence seen from thitung between maternal weight gain during pregnancy (X1), hemoglobin (X2), history of disease (X3) with $t$ table, there are variables unrelated signified with BBLR $(Y)$ that is the addition of mother's weight during pregnancy $(X 1)$, hemoglobin level (X2). As for the dominant factor that affects $L B W(Y)$ is a history of disease (X3). It can be concluded that a history of maternal illness in pregnancy affects the placenta, which causes a decrease in blood flow to the placenta resulting in a lack of oxygen supply and foodstuffs required by the fetus, leading to fetal growth disorders. Therefore it is necessary to Improve health services and more functioning of infrastructure available in the health.
\end{abstract}

Keywords: weight gain during pregnancy, hemoglobin level, history of disease, low birth weight $(L B W)$

\section{PENDAHULUAN}

Berat Bayi Lahir Rendah (BBLR) merupakan masalah kesehatan yang sering dialami pada sebagian besar masyarakat yang ditandai dengan berat lahir yang kurang dari 2500 gram. Kejadian BBLR pada dasarnya berhubungan dengan kurangnya pemenuhan nutrisi pada masa kehamilan ibu dan hal ini berhubungan dengan banyak faktor dan lebih utama pada masalah perekonomian keluarga sehingga pemenuhan kebutuhan konsumsi makanan pun kurang. Namun kejadian BBLR juga dapat terjadi tidak hanya karena aspek perekonomian, dimana kejadian BBLR dapat saja terjadi pada mereka dengan status perekonomian yang cukup. Dan hal ini terkait adanya pengaruh dari berbagai faktor yang pada penelitian ini mencakup faktor ibu (peningkatan berat badan ibu saat hamil, umur ibu, jarak hamil dan bersalin terlalu dekat, riwayat penyakit ibu dan faktor pekerjaan yang terlalu berat), faktor kehamilan (hamil dengan hidramnion, 
hamil kembar, anemia, perdarahan antepartum, komplikasi hamil) dan faktor janin (kelainan kongenital, infeksi dalam rahim) (Manuaba, 1998).

BBLR merupakan salah satu faktor resiko yang mempunyai kontribusi terhadap kematian bayi khususnya pada masa perinatal. Menurut Survey Demografi dan Kesehatan Indonesia (SDKI) 2016 angka kematian neonatal 34 per 1000 kelahiran hidup. Dalam satu tahun sekitar 89.000 bayi usia satu hari meninggal, artinya setiap 5 menit ada 1 bayi meninggal. Penyebab utama kematian neonatal tersebut adalah BBLR (29\%) dan asfiksia lahir (27\%) (DepKes, 2006). Hasil pengumpulan data indikator kesehatan propinsi yang berasal dari fasilitas pelayanan kesehatan propinsi, BBLR pada tahun 2016 berkisar antara 28,89\% (Jawa Tengah) dan 2,11\% (Jawa Timur), sedangkan pada tahun 2002 berkisar antara 2,29\% (Jawa Timur) dan $3,44 \%$ (DI Yogyakarta). Angka tersebut belum mencerminkan kondisi sebenarnya yang ada dimasyarakat karena belum semua berat badan bayi yang dilahirkan dapat dipantau oleh petugas kesehatan khususnya yang ditolong oleh dukun atau tenaga non kesehatan lainnya (Profil Kesehatan RI, 2016). Sedangkan proporsi BBLR di RSIA Fauziyah Tulungagung pada tahun 2010 sebanyak 74 bayi dari total persalinan 720 .

BBLR merupakan salah satu hasil dari ibu hamil yang menderita energi kronis dan akan mempunyai status gizi buruk. Pada ibu yang menderita penyakit kronis dapat mengakibatkan malnutrisi atau gizi kurang pada ibu. Selanjutnya suplai darah dan zat gizi ke janin juga dapat menurun. Suplai darah yang kurang, dapat menyebabkan ukuran plasenta kecil, transfer zat gizi untuk janin rendah dan akibatnya pertumbuhan janin terhambat, yang menyebabkan berat lahir bayi dibawah 2500 gram (Sayogo Savitri, 2007 ). BBLR terdiri atas BBLR kurang bulan, BBLR cukup bulan dan BBLR lebih bulan. BBLR kurang bulan khususnya BBLR dengan kehamilan kurang dari 35 minggu, umumnya mengalami penyulit seperti gangguan nafas, ikterus, infeksi (DepKes RI, 2006). Selain itu bayi dengan BBLR dapat terjadi sindrom gangguan pernafasan idiopatik (penyakit membran hialin), pneumonia aspirasi (karena refleks menelan dan batuk belum sempurna), perdarahan spontan dalam ventrikal otak lateral, hiperbilirubinemia, sindrom aspirasi mekoneum, hipoglikemia dan sangat rentan terhadap hipotermia dan infeksi (Saifuddin, 2002).

Upaya untuk menurunkan BBLR antara lain : 1) Meningkatkan pemeriksaan kehamilan secara berkala minimal $4 \mathrm{x}$ selama kurun kehamilan dan dimulai sejak umur kehamilan muda, ibu hamil yang diduga berisiko, terutama faktor resiko yang mengarah melahirkan bayi BBLR harus cepat dilaporkan, dipantau dan dirujuk pada institusi pelayanan kesehatan yang lebih mampu ;

2) Pemantapan KIE pada ibu hamil antara lain penyuluhan kesehatan tentang pertumbuhan dan perkembangan janin dalam rahim, tanda-tanda bahaya selama kehamilan dan perawatan diri selama kehamilan agar mereka dapat menjaga kesehatannya dan janin yang dikandung dengan baik ; 3) Hendaknya ibu dapat merencanakan persalinannya pada kurun umur reproduksi sehat (20-34 tahun) 4) Perlu dukungan sektor lain yang terkait untuk turut berperan dalam meningkatkan pendidikn ibu dan status ekonomi keluarga agar mereka dapat meningkatkan akses terhadap pemanfaatan pelayanan antenatal dan status gizi ibu selama hamil

\section{METODE PENELITIAN}

Metode yang digunakan dalam penelitian ini adalah metode penelitian analitik melalui survei dengan menggunakan observasi. Observasi dilakukan dengan menggunakan kartu status ibu atau berkas rekam medis. Berkas rekam medis digunakan untuk 
mendapatkan data mengenai karakteristik responden dan variabel penelitian yaitu kadar hemoglobin, perkembangan berat badan dan riwayat penyakit ibu serta kejadian berat bayi lahir rendah. Sedangkan data sekunder dalam penelitian ini diambil dari buku register ruang bayi untuk mendapatkan informasi mengenai gambaran kejadian berat bayi lahir rendah.

Sampel pada penelitiaan ini adalah seluruh bayi yang lahir di Rumah Sakit Ibu dan Anak Fauziyah Tulungagung pada bulan Maret 2016 sebanyak 30 bayi. Metode pengukuran variabel dalam penelitian ini menggunakan skala likert dimana jawaban setiap item instrumen mempunyai gradasi dari positif sampai negatif. Tehnik pengambilan sampel dalam penelitian ini menggunakan sampling jenuh. Sampilng jenuh merupakan tehnik penentuan sample bila semua anggota populasi digunakan sebagai sampel (Sugiono,2008). Sampel pada penelitiaan ini adalah seluruh bayi yang lahir di RSIA Fauziyah Tulungagung pada bulan Maret 2011 sebanyak 30 bayi.

Analisa data yang digunakan dalam penelitian ini adalah tehnik statistik inferensial dengan taraf signiftikan 5\% dan taraf kepercayaan (confidence level sebesar 95\%). Signiftikan level adalah kesediaan atau keberanian peneliti untuk secara maksimal mengambil resiko kesalahan dalam menguji hipotesis. Data dianalisis dengan menggunakan analisis regresi linier sederhana. Regresi linier sederhana didasarkan pada hubungan fungsional ataupun kausal antara satu variabel independen dengan satu variabel independen.

\section{HASIL DAN PEMBAHASAN}

\section{Faktor pertambahan berat badan}

Tabel 1 Distribusi Perkembangan berat badan

\begin{tabular}{|ccc|}
\hline Perkembangan berat badan & $\mathrm{F}$ & Prosentase \\
\hline$<6,5 \mathrm{~kg}$ & 7 & $23,3 \%$ \\
$6,5-16 \mathrm{~kg}$ & 23 & $76,7 \%$ \\
$>16 \mathrm{~kg}$ & - & - \\
\hline Total & 30 & $100 \%$ \\
\hline
\end{tabular}

Untuk distribusi perkembangan berat badan ibu seperti yang terdapat di tabel 1 dapat dilihat bahwa dari jumlah 30 ibu hamil yang mengalami perkembangan berat badan $>6,5 \mathrm{~kg}$ adalah 7 orang atau $23,3 \%$, ibu hamil yang berat badannya naik antara 6,5 sampai $16 \mathrm{~kg}$ sebanyak 23 orang atau $76,7 \%$. Hal ini dapat diambil kesimpulan bahwa perkembangan berat badan ibu selama kehamilan rata-rata cukup antara $6,5-16 \mathrm{~kg}$

\section{Faktor kadar hemoglobin}

Tabel 2 Distribusi kadar hemoglobin

\begin{tabular}{llll}
\hline \multicolumn{1}{c}{ Kadar hemoglobin } & & $\mathrm{F}$ & Prosentase $(\%)$ \\
\hline Anemia $(\mathrm{Hb}<11)$ & 26 & $86,7 \%$ \\
Tidak Anemia $(\mathrm{Hb}>11)$ & 4 & $13.3 \%$ \\
\hline Total & 30 & $100 \%$ \\
\hline
\end{tabular}

Dari daftar tabel 2 bahwa distribusi kadar mempunyai $\mathrm{Hb}<11$ gr\% atau 86,7\% hemoglobin ibu yang akan melahirkan sedangkan yang mempunyai $\mathrm{Hb}>11$ gr\% sebanyak 30 orang terdapat $26 \mathrm{ibu}$ yang ada 4 orang atau 13,3\%. 


\section{Faktor riwayat penyakit}

Tabel 3 Distribusi Riwayat penyakit

\begin{tabular}{ccc}
\hline Riwayat penyakit & F & Prosentase \\
\hline Skor 1-3 & - & - \\
Skor 4-6 & 8 & $26,7 \%$ \\
Skor 7-9 & 22 & $73,3 \%$ \\
\hline Total & 30 & $100 \%$ \\
\hline
\end{tabular}

Pada distribusi riwayat penyakit semakin tinggi nilai maka akan semakin (tabel 3 didapatkan skor riwayat penyakit $7-9$ sebanyak 22 orang $(73,3 \%)$ dan skor baik kondisi kesehatan ibu selama kehamilan

4-6 sebanyak 8 orang atau $73,3 \%$ dimana

\section{Berat bayi lahir rendah}

Tabel 4 Distribusi kejadian BBLR

\begin{tabular}{ccc}
\hline Kejadian BBLR & F & Prosentase \\
\hline BBLR & 3 & $10 \%$ \\
Tidak BBLR & 27 & $90 \%$ \\
\hline Total & 30 & $100 \%$ \\
\hline
\end{tabular}

Berdasarkan tael 4 distribusi kejadian BBLR terdapat 3 orang $(10 \%)$ dan

5. Hasil Analisis Hubungan antara kadar hemoglobin, perkembangan berat badan dan riwayat penyakit dengan berat bayi lahir rendah

Dalam bab sebelumnya telah dijelaskan bahwa penelitian ini adalah untuk mengetahui pengaruh antara penambahan berat badan ibu selama hamil $\left(\mathrm{X}_{1}\right)$, kadar hemoglobin $\left(\mathrm{X}_{2}\right)$ dan riwayat sisanya 27 orang $(90 \%)$ tidak mengalami BBLR.

Tabel 5 Nilai rata-rata kadar hemoglobin,perkembangan berat badan dan riwayat penyakit.

\begin{tabular}{llllll}
\hline & & Rata-rata & Terbesar & Terkecil & $\begin{array}{l}\text { Standart } \\
\text { Deviasi }\end{array}$ \\
\hline 1 & $\begin{array}{l}\text { Kadar hemoglobin } \\
2\end{array}$ & 9,523 & 11 & 8 & 1,023 \\
& $\begin{array}{l}\text { Peningkatan berat } \\
\text { badan }\end{array}$ & 9,433 & 15 & 3 & 3,636 \\
3 & Riwayat penyakit & 7,03 & 8 & 5 & 0,93 \\
4 & BBLR & 2,905 & 3,4 & 2,2 & 0,309 \\
\hline
\end{tabular}

Dari setiap variabel diatas pada tabel 5 terlihat bahwa untuk variabel nilai rata-rata kadar hemoglobin 9,523 maka penyakit $\left(\mathrm{X}_{3}\right)$ dengan berat bayi lahir rendah (Y). Dari analisis deskriptif yang telah dilakukan nilai rata-rata dari masinng-masing variabel bebas penambahan berat badan ibu selama hamil $\left(\mathrm{X}_{1}\right)$, kadar hemoglobin $\left(\mathrm{X}_{2}\right)$ dan riwayat penyakit $\left(\mathrm{X}_{3}\right)$ dan variabel tidak bebas BBLR (Y), dapat dilihat pada tabel 5 
$11 \mathrm{gr} \%$. Untuk variabel peningkatan berat badan nilai rata-rata 9,433 , hal ini memperlihatkan bahwa penambahan berat badan pada ibu hamil adalah cukup baik.
Dan untuk variabel riwayat penyakit nilai rata-rata 7,03 hal ini memperlihatkan bahwa rata-rata ibu mempunyai riwayat penyakit yang cukup.

Tabel 6 Analisis ragam regresi linier berganda,variabel kadar hemoglobin $\left(\mathrm{X}_{1}\right)$, Peningkatan berat badan $\left(\mathrm{X}_{2}\right)$, dan riwayat penyakit $(\mathrm{X})$ terhadap BBLR $(\mathrm{Y})$

\begin{tabular}{llllll}
\hline $\begin{array}{l}\text { Sumber } \\
\text { variasi }\end{array}$ & $\begin{array}{l}\text { Derajat } \\
\text { bebas }\end{array}$ & $\begin{array}{l}\text { Jumlah } \\
\text { kuadrat }\end{array}$ & Ragam & $\mathrm{F}_{\text {hitung }}$ & $\mathrm{F}_{0,05}$ \\
\hline Regresi & 3 & 2,519 & 0,840 & 86,346 & 2,98 \\
\hline Galat & 26 & 0,253 & 0,09724 & & \\
\hline TOTAL & 29 & 2,772 & & & \\
\hline
\end{tabular}

Dari tabel 6 diatas bahwa nilai $\mathrm{F}_{\text {hitung }} 86,346$ yang lebih besar dari $\mathrm{F}_{0,05}$ yaitu 2,98 yang berarti bahwa variabel bebas yaitu Penambahan berat badan ibu selama hamil $\left(\mathrm{X}_{1}\right)$, Kadar hemoglobin $\left(\mathrm{X}_{2}\right)$, dan riwayat penyakit $\left(\mathrm{X}_{3}\right)$ secara bersama-sama mempunyai hubungan secara signiftikan terhadap berat bayi lahir rendah $(\mathrm{Y})$. Lebih lanjut dilihat pada persamaan Nilai regresi linier berganda dibawah ini: $\mathrm{R}^{2}=0,909$ atau $90,90 \% ; \mathrm{Y}=0,771+0,09379$ $\mathrm{X}_{1}+0,02560 \mathrm{X}_{2}+0,142 \mathrm{X}_{3}$

Dari persamaan tersebut dapat dikemukakan / di interprestasikan bahwa : Semakin baik faktor riwayat penyakit ibu akan mempengaruhi semakin rendahnya kejadian BBLR dan juga dilihat bahwa untuk faktor hemoglobin dan peningkatan berat badan tidak mempengaruhi kejadian BBLR. determinasi $(\mathrm{R}=0,909)$, menunjukkan bahwa Pengaruh Penambahan berat badan ibu selama hamil $\left(\mathrm{X}_{1}\right)$, Kadar hemoglobin $\left(\mathrm{X}_{2}\right)$, dan riwayat penyakit $\left(\mathrm{X}_{3}\right)$ terhadap BBLR (Y) adalah sebesar 90,90 \% sedangkan 9,10\% dipengaruhi oleh faktor lain. Dan dapat disimpulkan bahwa semakin baik faktor riwayat penyakit ibu akan mempengaruhi semakin rendahnya kejadian BBLR,dan untuk faktor hemoglobin dan peningkatan berat badan tidak mempengaruhi kejadian BBLR.

Untuk pengujian hipotesis Pengaruh Penambahan berat badan ibu selama hamil $\left(\mathrm{X}_{1}\right)$, Kadar hemoglobin $\left(\mathrm{X}_{2}\right)$, dan riwayat penyakit $\left(\mathrm{X}_{3}\right)$ dengan berat bayi lahir rendah (Y) secara sendirisendiri, apabila dianggap bahwa masingmasing variabel bebas adalah bebas satu sama lain, pengaruh masing-masing variabel secara sendiri-sendiri dapat dilihat pada tabel 7 di bawah ini.

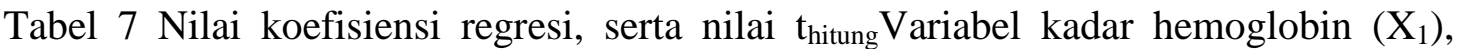
peningkatan berat badan $\left(\mathrm{X}_{2}\right)$, danriwayat penyakit $\left(\mathrm{X}_{3}\right)$.

\begin{tabular}{llll}
\hline Variabel & \multicolumn{3}{c}{ Nilai } \\
\cline { 2 - 4 } & Nilai koef.regresi & $\mathrm{t}_{\text {hitung }}$ & $\mathrm{t}_{0,05}$ \\
\hline Penambahan berat badan ibu & 0,02560 & 1,578 & \\
selama hamil $\left(\mathrm{X}_{1}\right)$ & & & \\
Kadar hemoglobin $\left(\mathrm{X}_{2}\right)$ & 0,09379 & 1,733 & 2,056 \\
Riwayat penyakit $\left(\mathrm{X}_{3}\right)$ & 0,142 & 4,983 & \\
\hline
\end{tabular}

Lebih lanjut bila dilihat pengaruh masing-masing variabel bebas adalah bebas satu sama lain. Hubungan masingmasing variabel sendiri-sendiri terdapat pada $\mathrm{t}_{\text {hitung, }}$, serta nampak bahwa variabel 
bebas yang berhubungan terhadap berat bayi lahir rendah adalah riwayat penyakit.

Dalam teori dijelaskan bahwa kejadian BBLR disebabkan oleh beberapa faktor, meliputi faktor ibu, faktor janin, keadaan sosial ekonomi yang rendah, kebiasaan/beban kerja fisik yang berat, faktor lingkungan dan pelayanan kesehatan. Faktor ibu yang dapat mempengaruhi dari kejadian BBLR diantaranya riwayat penyakit dan status gizi dimana dalam status gizi ini dapat dilihat dari penambahann berat badan ibu selama hamil dan pengukuran kadar hemoglobin. Dan dari penelitian didapatkan ketiga faktor diatas dapat mempengaruhi BBLR (Y), sedangkan faktor dominan yang berpengaruh adalah riwayat penyakit $\left(\mathrm{X}_{3}\right)$. Riwayat penyakit yang diderita oleh ibu pada kehamilan akan mempengaruhi pada plasenta, dimana menyebabkan penurunan aliran darah ke plasenta sehingga akan terjadi kekurangan suplai oksigen dan bahan makanan yang dibutuhkan oleh janin, dan ini menyebabkan gangguan pertumbuhan janin sehingga akan terjadinya persalinan prematur, bila terjadi dalam waktu yang lama dan kasus penyakit yang diderita berat bisa menyebabkan kematian pada janin.

\section{KESIMPULAN DAN SARAN}

\section{Kesimpulan}

Berdasarkan berat bayi lahir rendah hubungannya dengan kadar hemoglobin, perkembangan berat badan dan riwayat penyakit di Rumah Sakit Ibu Dan Anak Fauziyah Tulungagung, dapat ditarik beberapa simpulan sebagai berikut :

1. Untuk hipotesa secara bersama-sama, dilihat dimana nilai $\mathrm{f}$ hitung $(86,346)$ lebih besar dari $\mathrm{f}$ tabel $(2,98)$ maka penambahan berat badan ibu selama hamil $\left(\mathrm{X}_{1}\right)$, kadar hemoglobin $\left(\mathrm{X}_{2}\right)$, riwayat penyakit $\left(\mathrm{X}_{3}\right)$ secara signiftikan bersama-sama mempengaruhi variabel berat bayi lahir rendah (Y).
2. Untuk hipotesa pengaruh secara sendiri-sendiri dilihat dari $t_{\text {hitung }}$ antara penambahan berat badan ibu selama hamil $\left(\mathrm{X}_{1}\right)$, kadar hemoglobin $\left(\mathrm{X}_{2}\right)$, riwayat penyakit $\left(X_{3}\right)$ dengan $t_{\text {tabel }}$, ada variabel yang tidak berhubungan secara signiftikan dengan BBLR (Y) yaitu penambahan berat badan ibu selama hamil $\left(\mathrm{X}_{1}\right)$, kadar hemoglobin $\left(\mathrm{X}_{2}\right)$.

3. Untuk faktor dominan yang mempengaruhi BBLR (Y) adalah riwayat penyakit $\left(\mathrm{X}_{3}\right)$.

\section{Saran}

Meningkatkan pelayanan kesehatan dan lebih memfungsikan sarana prasarana yang tersedia di tempat kesehatan misalnya membuat leaflet tentang gizi seimbang selama hamil dan penyuluhan kesehatan tentang pertumbuhan dan perkembangan janin dalam rahim,bagaimana tanda-tanda bahaya selama kehamilan dan perawatan diri selama kehamilan, menyebarluaskan melalui posyandu, kelas antenatal dan saat berkunjung dengan cara yang lebih menarik. Bekerjasama dengan lintas sektor yang terkait untuk mengurangi angka kejadian BBLR.

\section{DAFTAR PUSTAKA}

Setiawan, A. dan saryono. 2010. Metodologi Penelitian kebidanan. Nuha Medika. Jakarta

Dinas Kesehatan Provinsi Jawa Timur. 2016. Profil Kesehatan 2016 Provinsi Jawa Timur. Tulungagung

Departemen Kesehatan RI. 2016. Ibu Sehat Bayi Sehat. Jakarta

DepkeS 2016. Kebijakan Depkes Dalam Penurunan AKI \&AKB. Jakarta

Hastono, S.P. 2006. Basic data Analysis for Health Research. Universitas Indonesia 
Llewellyn, J dan Derek. 2001. Dasardasar Obstetri dan Ginekologi. Hipokrates. Edisi 6. Jakarta

Huliana, M. 2001. Panduan menjalani Kehamilan sehat. Puspa Swara. Cetakan I : Jakarta

Jitowiyono, S. dan Weni Kristiyanasari. 2010. Asuhan Keperawatan Neonatus Dan Anak. Nuha Medika. Cetakan I: Jakarta

Kristyanasari, weni. 2010. Gizi Ibu Hamil. Nuha Medika. Jakarta

Kosim, SM, dan Ari Yunanto, Rizalya Dewi, Gatot IS, Ali Usman. 2008. Buku Ajar Neonatologi. Ikatan Dokter Anak Indonesia. Jakarta

Mansjoer, A, Dan Kuspuji T, Rahmi S, Wahyu I. W, Wiwiek S. 2000. Kapita Selekta Kedokteran. Media Aesculapius. Jakarta

Notoadmodjo, S. 2005. Metodologi Penelitian Kesehatan. Rineka Cipta. Jakarta

Proverawati, A. dan Siti Asfuah. 2009. Buku Ajar Gizi untuk Kebidanan. Nuha Medika. Cetakan I. Yogyakarta

Putmasari, Ira, 2010. Hubungan Status Gizi Ibu Hamil dengan Kejadian BBLR di Puskesmas bangetayu Semaranag Tahun 2010. Semarang. Universitas Muhammadiyah Semarang. karya Tulis Ilmiah

Rekapitulasi Dinas Kesehatan kabupaten Tulungagung 2016

Rekapitulasi Profil Kesehatan RSIA Fauziyah. 2016. Tulungagung

Sadikin, M. 2001. Biokimia darah. Widya Medika. Jakarta

Saifuddin dkk. 2007. Buku Acuan Nasional Pelayanan Kesehatan Maternal dan Neonatal. PT Bina Pustaka
Sarwono Prawirohardjo: Jakarta 2008. Ilmu Kebidanan. PT Bina Pustaka_Sarwono Praworihardjo: Jakarta

Setianingrum, S.I.W. 2005. Hubungan Antara kenaikan Berat Badan, Lingkar Lengan Atas, dan Kadar Hemoglobin Ibu Hamil Trimester III dengan Berat Bayi Lahir di Puskesmas Ampel I boyolali tahun 2005. Semarang, Universitas Negeri Semarang. Jurnal

Setiawan, A. dan Saryono. 2010. Metodologi Penelitian Kebidanan. Nuha Medika : Jakarta

Soebroto. 2009. Cara Mudah Mengatasi Problem Anemia. Bangkit. Cetakan I: Yogyakarta

Sugiyono, 2007. Statistika Untuk Penelitian. Alfabeta. Cetakan Kesebelas: Bandung.

Supariasa, I.D.N. Bahyar B. dan Ibnu F. 2001. Penilaian Status Gizi. EGC : Jakarta 